\title{
THE CORRELATION BETWEEN MANDIBULAR LENGTH VERSUS BODY MASS AND AGE IN THE EUROPEAN ROE DEER (CAPREOLUS CAPREOLUS L.)
}

\author{
HANZAL, V. ${ }^{1,4}$ - JANISZEWSKI, P. ${ }^{2 *}-$ TAJCHMAN, K. $^{3}$ - KOŠINOVÁ, K. ${ }^{1}$ \\ ${ }^{1}$ Czech University of Life Science \\ Kamycka 129, 16500 Praha 6 - Suhdol, Czech Republic \\ ${ }^{2}$ University of Warmia and Mazury in Olsztyn \\ Oczapowskiego 5, 10-718 Olsztyn, Poland \\ ${ }^{3}$ University of Life Sciences in Lublin \\ Akademicka 13, 20-950 Lublin, Poland \\ ${ }^{4}$ University of South Bohemia in Česke Budejovice \\ Studentska 13, 370-05 Česke Budejovice, Czech Republic \\ *Corresponding author \\ e-mail: janisz@uwm.edu.pl \\ (Received 12 $2^{\text {th }}$ Jun 2017; accepted $20^{\text {th }}$ Sep 2017)
}

\begin{abstract}
This study investigated the correlation between mandibular length versus the age and body mass of European roe deer. Mandibular length was measured in 7560 roe deer (3888 females and 3672 fawns younger than 1 year) that were hunter-harvested in the Czech Republic in 2007-2012. The body mass and age of every animal were determined. Average mandibular length was determined at less than $130 \mathrm{~mm}$ in fawns and more than $153 \mathrm{~mm}$ in adult females. The greatest increase in mandibular length and body mass of $24.8 \mathrm{~mm}$ and $5.3 \mathrm{~kg}$, respectively, was observed in animals aged up to 4 years. In older roe deer, mandibular length increased at a slower rate and remained fairly constant. Mandibular length increased with body mass, and the cross-correlation coefficient was determined at 0.8255 . The results of this study indicate that mandibular length is a useful metric for describing the quality of roe deer populations and individuals.
\end{abstract}

Keywords: craniometry, game management, individual development, morphometry, population

\section{Introduction}

The European roe deer (Capreolus capreolus) is a species with high levels of morphological variation. Twenty-six subspecies of roe deer have been identified based on phenotypic and geographic variations in roe deer populations (Mayr, 1942; Sempéré et al., 1996). Differences in cranial measurements are significant determinants of interpopulation variability in the species (Kulak and Wajdzik, 2009) and other wild cervids (Markov, 2014). Cranial dimensions are influenced by primary production which is responsible for the isolation of local populations and differences in cranial morphology. According to Stubbe and Passarge (1979) and Zedja and Koubek (1988), the body mass of animals is directly linked with habitat productivity which is influenced by soil type, vegetation, population density and ecotone length. Animals that forage on woody plants have shorter and wider crania than animals that feed mainly on herbaceous plants (Aragon et al., 1998). The mandible is one of the first bones in the body to ossify (Hewison et al., 1996), and mandibular length in adult animals is determined mainly by environmental conditions in early life. 
In wild animals, including game, the mandible constitutes interesting research material because it does not have any economic value. Analyses of mandibular measurements support the search for new parameters to describe variations in local populations and the quality of their habitats (Sheremetyeva and Sheremetyev, 2008; Hanzal et al., 2012; Mendoza et al., 2002).

The aim of this study was to investigate the relationship between mandibular length versus the age and body mass of roe deer.

\section{Materials and Methods}

The study was performed on mandibles of the European roe deer Capreolus capreolus that were hunter-harvested in the Žd'ár nad Sázavou District of the Czech Republic in 2007-2012. Mandibular length was measured in 7560 roe deer, including 3888 females (does) and 3672 individuals aged up to 1 year (fawns).

Roe deer were hunter harvested in the Žd'ár nad Sázavou District, Jihlava county of the Vysočina Region (Czech Republic) at the altitude of around $500 \mathrm{~m}$ above sea level. The district has an area of $1579 \mathrm{~km}^{2}$ (Misar et al., 1983). Water bodies occupy $2.9 \%$ of the district's area. Agricultural land and forests (where the animals were harvested) have a similar share of the district's area at around $49 \%$ and $41 \%$, respectively (Czech Statistical Office, 2014).

Mandibular length ( $\mathrm{mm}$ ) was measured between the zygomatic arch and incisor root to the nearest $0.1 \mathrm{~mm}$. The animals' body mass $(\mathrm{kg})$ was determined to the nearest 0.1 $\mathrm{mm}$, immediately after harvesting (in the hunting site) and before evisceration. Potential blood loss associated with hunter harvesting was not subtracted from body mass measurements.

The animals' age was estimated based on physiological features and the wear of mandibular teeth (Lochman, 1987; Vach, 1993). Due to the extensive experimental material (7560 mandibles), the age of the analyzed roe deer could not be determined with the use of laboratory methods for organizational reasons.

The following variables were processed statistically:

- body mass,

- mandibular length,

- age,

- harvest date.

The data were expressed as means \pm standard error of the mean (SEM). The results were analyzed statistically by one-way ANOVA, and the significance of differences between groups was determined with Duncan's multiple range test at a significance level of $\mathrm{P} \leq 0.05$. All calculations were carried out in the Statistica 10.0 program (StatSoft, 2011).

\section{Results}

Average mandibular length was determined at less than $130 \mathrm{~mm}$ in fawns and at more than $153 \mathrm{~mm}$ in adult females (Table 1).

The greatest increase in mandibular length and body mass of $24.8 \mathrm{~mm}$ and $5.3 \mathrm{~kg}$, respectively, was observed in animals aged up to 4 years. In older animals, mandibular length increased at a slower rate and remained fairly constant (Fig. 1). 
Table 1. Average body mass ( $\mathrm{kg})$ and mandibular length $(\mathrm{mm})$ in fawns and does

\begin{tabular}{c|c|c}
\hline Trait & Fawns $(\mathbf{n}=\mathbf{3 6 7 2})$ & Does $(\mathbf{n}=\mathbf{3 ~ 8 8 8})$ \\
\hline Average body mass & 7.96 & 13.03 \\
Average mandibular length & 129.30 & 153.44 \\
\hline
\end{tabular}

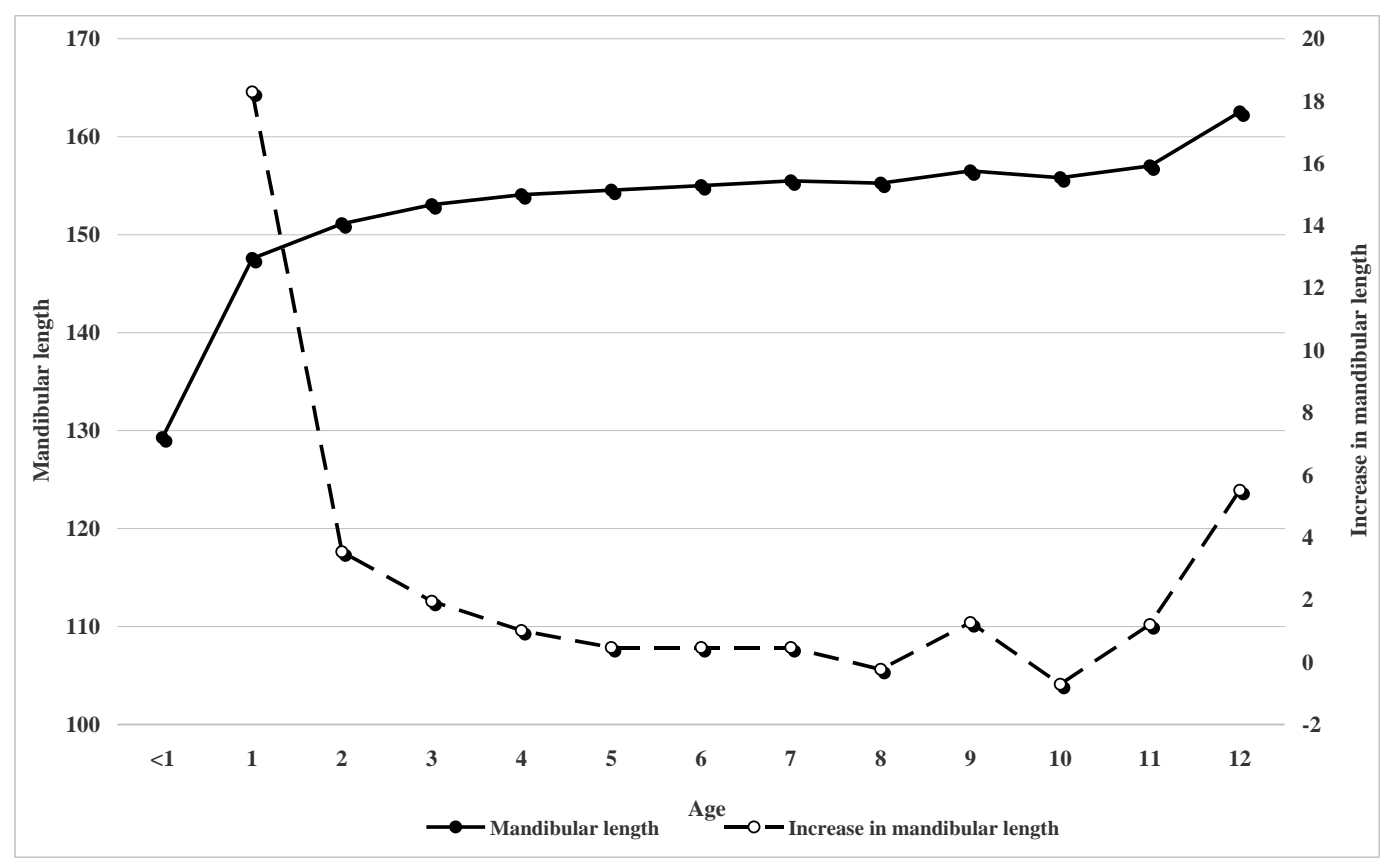

Figure 1. Average mandibular length [mm] and increase in mandibular length [ $\mathrm{mm}]$ in roe deer aged to 12 years

The greatest difference in mandibular length was observed between 2-year-old individuals and fawns, and it reached $18.28 \mathrm{~mm}$ on average (Fig. 1). The noted difference accounted for around $60 \%$ of the total increase in mandibular length in the analyzed period of life. The observed difference was highly significant (Table 2).

According to estimates, the youngest animals were approximately 5 months old, and the oldest individual was 12 years old in September of the first experimental year, which suggests that the overall increase in mandibular length in the examined period of life was approximately $30.4 \mathrm{~mm}$.

Mandibular length increased with body mass (Table 2, Fig. 1), and the value of the cross-correlation coefficient reached 0.8255 . It should be noted that body mass was characterized by greater variations than mandibular length across the examined age groups (Table 2).

In females, average mandibular length was determined at $153.44 \mathrm{~mm}$, and this value was noted in hypothetical animals with average body mass of $13.03 \mathrm{~kg}$, and average age of 4.4 years (Table 1). In fawns, average mandibular length reached $129.3 \mathrm{~mm}$, and it was observed in hypothetical animals with average body mass of $7.96 \mathrm{~kg}$, and average age of 5-7 months.

The average mandibular length of fawns harvested in each year of the study was analyzed (Table 2, Fig. 2). The measured parameter was higher in 2008, 2009 and 2012 than in the remaining years of the experiment. 
Table 2. Mandibular length (ML) [mm] and body mass (BM) [kg] in differently aged [year] roe deer hunter-harvested in 2007-2012 (mean \pm SD) $A, B, C, D-p \leq 0,01 ; a, b, c, d-p \leq 0,05$

\begin{tabular}{|c|c|c|c|c|c|c|c|c|c|c|c|c|c|c|}
\hline & Age & $<1$ & 1 & 2 & 3 & 4 & 5 & 6 & 7 & 8 & 9 & 10 & 11 & 12 \\
\hline \multirow{3}{*}{ ్ㅗํ } & $\mathbf{N}$ & 588 & 62 & 67 & 57 & 58 & 56 & 62 & 63 & 69 & 60 & 76 & - & - \\
\hline & ML & $\begin{array}{c}129.02 \mathrm{~A} \\
\pm 3.27\end{array}$ & $\begin{array}{c}147.22 \mathrm{~B} \\
\pm 3.18\end{array}$ & $\begin{array}{c}151.10 \mathrm{~B} \\
\pm 4.01\end{array}$ & $\begin{array}{c}152.34 \mathrm{~B} \\
\pm 4.16\end{array}$ & $\begin{array}{c}154.21 \mathrm{~B} \\
\pm 4.46\end{array}$ & $\begin{array}{c}154.91 \mathrm{~B} \\
\pm 4.56\end{array}$ & $\begin{array}{c}154.88 \mathrm{~B} \\
\pm 4.62\end{array}$ & $\begin{array}{c}155.41 \mathrm{~B} \\
\pm 4.89\end{array}$ & $\begin{array}{c}156.31 \mathrm{~B} \\
\pm 4.93\end{array}$ & $\begin{array}{c}154.42 \mathrm{~B} \\
\pm 4.86\end{array}$ & $\begin{array}{c}157.21 \mathrm{~B} \\
\pm 4.92\end{array}$ & - & - \\
\hline & BM & $\begin{array}{c}8.3 \mathrm{~A} \\
\pm 0.90\end{array}$ & $\begin{array}{c}11.0 \mathrm{BC} \\
\pm 1.11\end{array}$ & $\begin{array}{l}13.2 \mathrm{~B} \\
\pm 1.29\end{array}$ & $\begin{array}{l}13.6 \mathrm{~B} \\
\pm 1.31\end{array}$ & $\begin{array}{l}13.6 \mathrm{~B} \\
\pm 1.39\end{array}$ & $\begin{array}{l}13.8 \mathrm{~B} \\
\pm 1.45\end{array}$ & $\begin{array}{l}13.9 \mathrm{~B} \\
\pm 1.51\end{array}$ & $\begin{array}{l}14.5 \mathrm{~B} \\
\pm 1.61\end{array}$ & $\begin{array}{l}13.2 \mathrm{~B} \\
\pm 1.48\end{array}$ & $\begin{array}{l}14.7 \mathrm{~B} \\
\pm 1.57\end{array}$ & $\begin{array}{c}\text { 15.2BD } \\
\pm 1.44\end{array}$ & - & - \\
\hline \multirow{3}{*}{ 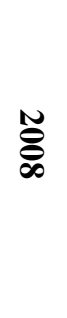 } & $\mathbf{N}$ & 665 & 63 & 68 & 58 & 60 & 74 & 63 & 64 & 71 & 74 & 51 & 12 & \\
\hline & ML & $\begin{array}{c}130.41 \mathrm{~A} \\
\pm 3.11\end{array}$ & $\begin{array}{c}149.42 \mathrm{~B} \\
\pm 3.15\end{array}$ & $\begin{array}{c}151.61 \mathrm{~B} \\
\pm 3.99\end{array}$ & $\begin{array}{c}153.04 \mathrm{~B} \\
\pm 4.12\end{array}$ & $\begin{array}{c}154.41 \mathrm{~B} \\
\pm 4.55\end{array}$ & $\begin{array}{c}154.15 \mathrm{~B} \\
\pm 4.67\end{array}$ & $\begin{array}{c}154.51 \mathrm{~B} \\
\pm 4.57\end{array}$ & $\begin{array}{c}155.21 \mathrm{~B} \\
\pm 4.68\end{array}$ & $\begin{array}{c}154.57 \mathrm{~B} \\
\pm 4.87\end{array}$ & $\begin{array}{c}155.68 \mathrm{~B} \\
\pm 4.91\end{array}$ & $\begin{array}{c}155.32 \mathrm{~B} \\
\pm 4.86\end{array}$ & $\begin{array}{c}157.09 \mathrm{~B} \\
\pm 4.91\end{array}$ & - \\
\hline & BM & $\begin{array}{c}8.7 \mathrm{~A} \\
\pm 1.01\end{array}$ & $\begin{array}{l}13.2 \mathrm{~B} \\
\pm 1.09\end{array}$ & $\begin{array}{l}13.4 \mathrm{~B} \\
\pm 1.19\end{array}$ & $\begin{array}{l}12.5 \mathrm{~B} \\
\pm 1.16\end{array}$ & $\begin{array}{l}14.4 \mathrm{~B} \\
\pm 1.42\end{array}$ & $\begin{array}{l}13.2 \mathrm{~B} \\
\pm 1.37\end{array}$ & $\begin{array}{l}13.4 \mathrm{~B} \\
\pm 1.41\end{array}$ & $\begin{array}{l}13.6 \mathrm{~B} \\
\pm 1.48\end{array}$ & $\begin{array}{l}13.4 \mathrm{~B} \\
\pm 1.42\end{array}$ & $\begin{array}{l}11.6 \mathrm{~B} \\
\pm 1.28\end{array}$ & $\begin{array}{l}12.7 \mathrm{~B} \\
\pm 1.31\end{array}$ & $\begin{array}{l}13.7 \mathrm{~B} \\
\pm 1.50\end{array}$ & - \\
\hline \multirow{3}{*}{ స్రి } & $\mathbf{N}$ & 597 & 61 & 58 & 55 & 75 & 56 & 61 & 63 & 73 & 59 & 75 & 7 & \\
\hline & ML & $\begin{array}{c}130.44 \mathrm{~A} \\
\pm 2.99\end{array}$ & $\begin{array}{c}144.12 \mathrm{~B} \\
\pm 3.10\end{array}$ & $\begin{array}{c}152.08 \mathrm{~B} \\
\pm 4.11\end{array}$ & $\begin{array}{c}154.22 \mathrm{~B} \\
\pm 4.21\end{array}$ & $\begin{array}{c}154.56 \mathrm{~B} \\
\pm 4.99\end{array}$ & $\begin{array}{c}155.71 \mathrm{~B} \\
\pm 4.66\end{array}$ & $\begin{array}{c}156.48 \mathrm{~B} \\
\pm 4.68\end{array}$ & $\begin{array}{c}156.49 \mathrm{~B} \\
\pm 4.57\end{array}$ & $\begin{array}{c}156.82 \mathrm{~B} \\
\pm 4.69\end{array}$ & $\begin{array}{c}156.69 \mathrm{~B} \\
\pm 4.88\end{array}$ & $\begin{array}{c}157.37 \mathrm{~B} \\
\pm 4.99\end{array}$ & $\begin{array}{c}154.98 \mathrm{~B} \\
\pm 4.82\end{array}$ & - \\
\hline & BM & $\begin{array}{l}8.8 \mathrm{Aa} \\
\pm 0.99\end{array}$ & $\begin{array}{c}11.2 \mathrm{Bbc} \\
\pm 1.16\end{array}$ & $\begin{array}{l}12.6 \mathrm{~B} \\
\pm 1.21\end{array}$ & $\begin{array}{l}12.4 \mathrm{~B} \\
\pm 1.18\end{array}$ & $\begin{array}{c}13.6 \mathrm{Bd} \\
\pm 1.32\end{array}$ & $\begin{array}{c}\text { 13.8Bd } \\
\pm 1.50\end{array}$ & $\begin{array}{c}\text { 13.9Bd } \\
\pm 1.49\end{array}$ & $\begin{array}{c}\text { 13.3Bd } \\
\pm 1.43\end{array}$ & $\begin{array}{l}\text { 13.4Bd } \\
\pm 1.46\end{array}$ & $\begin{array}{c}\text { 13.3Bd } \\
\pm 1.44\end{array}$ & $\begin{array}{c}14.2 \mathrm{Bd} \\
\pm 1.66\end{array}$ & $\begin{array}{l}12.9 \mathrm{~B} \\
\pm 1.27\end{array}$ & - \\
\hline$\stackrel{N}{0}$ & $\mathbf{N}$ & 641 & 57 & 60 & 55 & 61 & 59 & 69 & 61 & 68 & 70 & 69 & - & 7 \\
\hline
\end{tabular}




\begin{tabular}{|c|c|c|c|c|c|c|c|c|c|c|c|c|c|c|}
\hline & ML & $\begin{array}{c}129.98 \mathrm{~A} \\
\pm 2.97\end{array}$ & $\begin{array}{c}147.67 \mathrm{~B} \\
\pm 3.59\end{array}$ & $\begin{array}{c}150.25 \mathrm{~B} \\
\pm 3.98\end{array}$ & $\begin{array}{c}153.17 \mathrm{~B} \\
\pm 4.19\end{array}$ & $\begin{array}{c}153.64 \mathrm{~B} \\
\pm 4.50\end{array}$ & $\begin{array}{c}154.58 \mathrm{~B} \\
\pm 4.59\end{array}$ & $\begin{array}{c}153.79 \mathrm{~B} \\
\pm 4.81\end{array}$ & $\begin{array}{c}154.78 \mathrm{~B} \\
\pm 4.69\end{array}$ & $\begin{array}{c}154.89 \mathrm{~B} \\
\pm 4.76\end{array}$ & $\begin{array}{c}155.78 \mathrm{~B} \\
\pm 4.81\end{array}$ & $\begin{array}{c}154.29 \mathrm{~B} \\
\pm 4.88\end{array}$ & - & $\begin{array}{c}162.51 \mathrm{~B} \\
\pm 5.01\end{array}$ \\
\hline & BM & $\begin{array}{l}8.9 \mathrm{Aa} \\
\pm 0.79\end{array}$ & $\begin{array}{l}11.3 \mathrm{bc} \\
\pm 1.08\end{array}$ & $\begin{array}{l}12.5 \mathrm{~B} \\
\pm 1.30\end{array}$ & $\begin{array}{l}13.1 \mathrm{~B} \\
\pm 1.41\end{array}$ & $\begin{array}{c}13.4 \mathrm{Bd} \\
\pm 1.38\end{array}$ & $\begin{array}{c}13.8 \mathrm{Bd} \\
\pm 1.47\end{array}$ & $\begin{array}{l}13.2 \mathrm{~B} \\
\pm 1.39\end{array}$ & $\begin{array}{c}13.9 \mathrm{Bd} \\
\pm 1.48\end{array}$ & $\begin{array}{c}14.1 \mathrm{Bd} \\
\pm 1.58\end{array}$ & $\begin{array}{c}14.2 \mathrm{Bd} \\
\pm 1.63\end{array}$ & $\begin{array}{l}12.3 \mathrm{~B} \\
\pm 1.32\end{array}$ & - & $\begin{array}{l}12.5 \mathrm{~B} \\
\pm 1.36\end{array}$ \\
\hline \multirow{3}{*}{$\stackrel{\widetilde{G}}{\mathscr{G}}$} & $\mathbf{N}$ & 583 & 69 & 66 & 56 & 70 & 63 & 59 & 66 & 65 & 61 & 71 & - & - \\
\hline & ML & $\begin{array}{c}128.22 \mathrm{~A} \\
\pm 3.01\end{array}$ & $\begin{array}{c}148.60 \mathrm{~B} \\
\pm 3.44\end{array}$ & $\begin{array}{c}150.21 \mathrm{~B} \\
\pm 4.00\end{array}$ & $\begin{array}{c}153.31 \mathrm{~B} \\
\pm 4.13\end{array}$ & $\begin{array}{c}154.23 \mathrm{~B} \\
\pm 4.87\end{array}$ & $\begin{array}{c}154.46 \mathrm{~B} \\
\pm 4.63\end{array}$ & $\begin{array}{c}154.49 \mathrm{~B} \\
\pm 4.73\end{array}$ & $\begin{array}{c}155.22 \mathrm{~B} \\
\pm 4.79\end{array}$ & $\begin{array}{c}154.29 \mathrm{~B} \\
\pm 4.69\end{array}$ & $\begin{array}{c}162.02 \mathrm{~B} \\
\pm 4.92\end{array}$ & $\begin{array}{c}156.50 \mathrm{~B} \\
\pm 4.87\end{array}$ & - & - \\
\hline & BM & $\begin{array}{c}8.9 \mathrm{~A} \\
\pm 0.88\end{array}$ & $\begin{array}{c}12.7 \\
\pm 1.14\end{array}$ & $\begin{array}{c}12.4 \\
\pm 1.27\end{array}$ & $\begin{array}{c}13.3 \\
\pm 1.29\end{array}$ & $\begin{array}{c}13.6 \\
\pm 1.37\end{array}$ & $\begin{array}{c}13.8 \\
\pm 1.49\end{array}$ & $\begin{array}{c}13.9 \\
\pm 1.45\end{array}$ & $\begin{array}{c}13.3 \\
\pm 1.39\end{array}$ & $\begin{array}{c}13.5 \\
\pm 1.39\end{array}$ & $\begin{array}{c}14.1 \\
\pm 1.50\end{array}$ & $\begin{array}{c}12.5 \\
\pm 1.37\end{array}$ & - & - \\
\hline \multirow{3}{*}{$\stackrel{N}{\stackrel{N}{N}}$} & $\mathbf{N}$ & 598 & 69 & 71 & 58 & 68 & 66 & 68 & 70 & 62 & 70 & 73 & - & - \\
\hline & ML & $\begin{array}{c}129.51 \mathrm{~A} \\
\pm 2.79\end{array}$ & $\begin{array}{c}145.62 \mathrm{~B} \\
\pm 3.27\end{array}$ & $\begin{array}{c}152.21 \mathrm{~B} \\
\pm 4.08\end{array}$ & $\begin{array}{c}152.64 \mathrm{~B} \\
\pm 4.17\end{array}$ & $\begin{array}{c}154.44 \mathrm{~B} \\
\pm 4.94\end{array}$ & $\begin{array}{c}154.39 \mathrm{~B} \\
\pm 4.60\end{array}$ & $\begin{array}{c}156.22 \mathrm{~B} \\
\pm 4.70\end{array}$ & $\begin{array}{c}156.40 \mathrm{~B} \\
\pm 4.69\end{array}$ & $\begin{array}{c}154.91 \mathrm{~B} \\
\pm 4.83\end{array}$ & $\begin{array}{c}157.62 \mathrm{~B} \\
\pm 4.85\end{array}$ & $\begin{array}{c}156.89 \mathrm{~B} \\
\pm 4.93\end{array}$ & - & - \\
\hline & BM & $\begin{array}{l}8.9 \mathrm{Aa} \\
\pm 1.03\end{array}$ & $\begin{array}{c}10.5 \mathrm{bCc} \\
\pm 1.11\end{array}$ & $\begin{array}{c}12.7 \mathrm{Bd} \\
\pm 1.19\end{array}$ & $\begin{array}{c}12.6 \mathrm{Bd} \\
\pm 1.20\end{array}$ & $\begin{array}{c}\text { 13.1BD } \\
\pm 1.38\end{array}$ & $\begin{array}{c}12.5 \mathrm{Bd} \\
\pm 1.33\end{array}$ & $\begin{array}{c}\text { 13.1BD } \\
\pm 1.47\end{array}$ & $\begin{array}{c}\text { 13.1BD } \\
\pm 1.13\end{array}$ & $\begin{array}{c}12.1 \mathrm{Bd} \\
\pm 1.31\end{array}$ & $\begin{array}{c}\text { 13.6BD } \\
\pm 1.38\end{array}$ & $\begin{array}{c}12.7 \mathrm{Bd} \\
\pm 1.40\end{array}$ & - & - \\
\hline \multirow{3}{*}{ 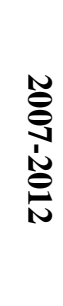 } & $\mathbf{N}$ & 3672 & 381 & 390 & 339 & 392 & 374 & 382 & 387 & 408 & 394 & 415 & 19 & 7 \\
\hline & ML & $\begin{array}{c}129.27 \mathrm{~A} \\
\pm 3.01\end{array}$ & $\begin{array}{c}147.56 \mathrm{~B} \\
\pm 3.49\end{array}$ & $\begin{array}{c}151.10 \mathrm{~B} \\
\pm 4.09\end{array}$ & $\begin{array}{c}153.05 \mathrm{~B} \\
\pm 4.18\end{array}$ & $\begin{array}{c}154.06 \mathrm{~B} \\
\pm 4.88\end{array}$ & $\begin{array}{c}154.53 \mathrm{~B} \\
\pm 4.62\end{array}$ & $\begin{array}{c}155.00 \mathrm{~B} \\
\pm 4.79\end{array}$ & $\begin{array}{c}155.47 \mathrm{~B} \\
\pm 4.77\end{array}$ & $\begin{array}{c}155.24 \mathrm{~B} \\
\pm 4.81\end{array}$ & $\begin{array}{c}156.51 \mathrm{~B} \\
\pm 4.89\end{array}$ & $\begin{array}{c}155.80 \mathrm{~B} \\
\pm 4.94\end{array}$ & $\begin{array}{c}157.00 \mathrm{~B} \\
\pm 4.88\end{array}$ & $\begin{array}{c}162.51 \mathrm{E} \\
\pm 5.01\end{array}$ \\
\hline & BM & $\begin{array}{c}7.8 \mathrm{~A} \\
\pm 0.97\end{array}$ & $\begin{array}{c}11.9 \mathrm{Bc} \\
\pm 1.10\end{array}$ & $\begin{array}{l}12.7 \mathrm{~B} \\
\pm 1.24\end{array}$ & $\begin{array}{l}12.9 \mathrm{~B} \\
\pm 1.30\end{array}$ & $\begin{array}{c}13.3 \mathrm{Bcd} \\
\pm 1.41\end{array}$ & $\begin{array}{c}13.2 \mathrm{Bd} \\
\pm 1.49\end{array}$ & $\begin{array}{c}13.2 \mathrm{Bd} \\
\pm 1.52\end{array}$ & $\begin{array}{c}13.4 \mathrm{Bd} \\
\pm 1.48\end{array}$ & $\begin{array}{c}13.3 \mathrm{Bd} \\
\pm 1.50\end{array}$ & $\begin{array}{c}13.3 \mathrm{Bd} \\
\pm 1.48\end{array}$ & $\begin{array}{c}13.2 \mathrm{Bd} \\
\pm 1.52\end{array}$ & $\begin{array}{c}13.3 \mathrm{Bd} \\
\pm 1.36\end{array}$ & $\begin{array}{l}12.5 \mathrm{~B} \\
\pm 1.36\end{array}$ \\
\hline
\end{tabular}


Individuals that were harvested later in the year (December) and were, therefore, older, were characterized by longer mandibles than fawns harvested in earlier months. Mandibular length was approximately $10.6 \mathrm{~mm}$ higher in roe deer harvested in December than in individuals harvested in September, and it was determined at 133.6 $\mathrm{mm}$ and $123.0 \mathrm{~mm}$, respectively (Table 3, Fig. 2).

No significant differences in mandibular length were noted across the experimental years.

Table 3. Mandibular length [mm] in fawns younger than 1 year in different months of the experimental years

\begin{tabular}{c|c|c|c|c|c|c|c}
\hline \multicolumn{2}{c|}{} & \multicolumn{6}{c}{ Year } \\
\cline { 3 - 8 } Month & 2007 & 2008 & 2009 & 2010 & 2011 & 2012 \\
\hline \multirow{2}{*}{ Sept } & $\mathrm{N}$ & 109 & 84 & 99 & 88 & 78 & 101 \\
& mean $\pm \mathrm{SD}$ & $122.6 \pm 2.92$ & $123.6 \pm 2.61$ & $124.4 \pm 2.55$ & $123.0 \pm 2.99$ & $121.4 \pm 2.74$ & $123.4 \pm 2.77$ \\
Oct & $\mathrm{N}$ & 190 & 213 & 184 & 115 & 99 & 126 \\
& mean $\pm \mathrm{SD}$ & $127.3 \pm 2.61$ & $127.3 \pm 2.66$ & $128.5 \pm 2.99$ & $126.6 \pm 3.01$ & $126.0 \pm 3.22$ & $126.4 \pm 2.97$ \\
& $\mathrm{~N}$ & 211 & 194 & 174 & 234 & 168 & 184 \\
Nov & mean $\pm \mathrm{SD}$ & $130.3 \pm 2.97$ & $131.8 \pm 2.99$ & $131.5 \pm 2.99$ & $131.4 \pm 3.10$ & $131.2 \pm 2.98$ & $132.2 \pm 3.12$ \\
& $\mathrm{~N}$ & 78 & 174 & 149 & 195 & 238 & 187 \\
Dec & $\mathrm{mean} \pm \mathrm{SD}$ & $132.7 \pm 3.11$ & $133.9 \pm 3.10$ & $134.1 \pm 3.05$ & $133.2 \pm 3.12$ & $133.5 \pm 2.99$ & $134.3 \pm 2.99$ \\
\hline
\end{tabular}

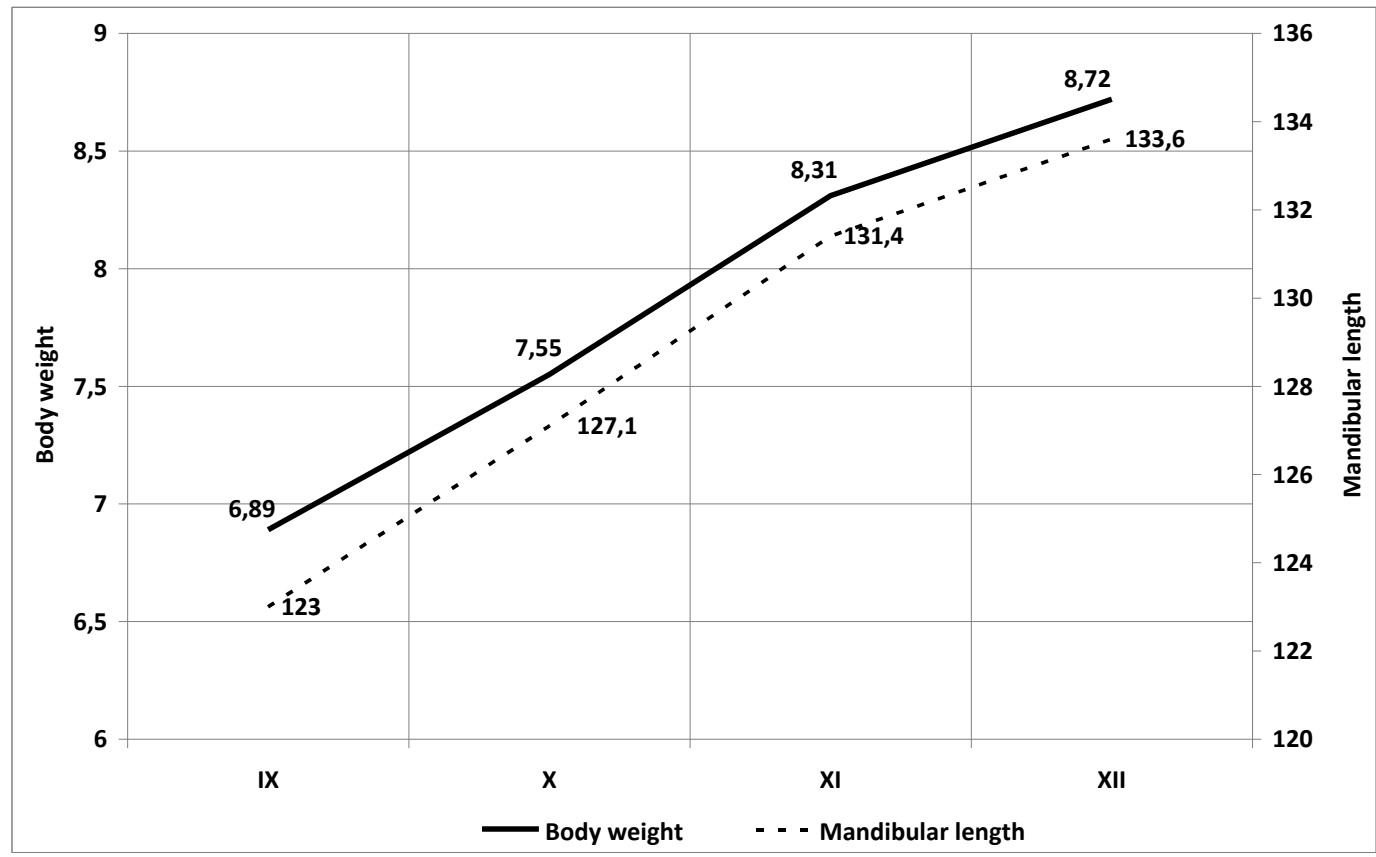

Figure 2. Average body mass [ $\mathrm{kg}]$ and mandibular length $[\mathrm{mm}]$ in one-year-old roe deer fawns hunter-harvested in different months of the year 


\section{Discussion}

In animals, selected elements of the skeletal system are often used as retrospective indices to describe bodily dimensions, physiological development and resistance to seasonal changes in food availability (Zanneśe et al., 2006b). Slow bone growth observed under unfavorable environmental conditions can be compensated for in periods when food is more abundant (Bailey, 1984). Animal density, habitat quality, genetic structure and climate are significant predictors of body size in ungulates. Mandibular length can be an important indicator of physiological status in many cervid species. Animals living in more supportive environments are characterized by more developed maxillary and mandibular bones (Høye and Forchhammer, 2006).

Wustinger et al. (2005) analyzed 29 mandibles of female roe deer from the Polish region of Wielkopolska. Mandibular length was determined at around $132 \mathrm{~mm}$ in fawns and $156 \mathrm{~mm}$ in adult individuals. In our study, the examined mandibles were shorter at $129.3 \mathrm{~mm}$ in fawns and $153.4 \mathrm{~mm}$ in adult females. The results reported by Wustinger et al. (2005) could indicate that habitat conditions in the examined region were more favorable for roe deer.

In our study, average mandibular length in female roe deer from Czech lowland regions was more than $2 \mathrm{~cm}$ lower than that noted in does inhabiting the Prokletije mountain range in Serbia, where this parameter was determined at $156.55 \mathrm{~mm}$ (Labus et al., 2010). No significant differences in mandibular length were observed between males and females. The average mandibular length of roe deer in Bosnia and Herzegovina (not adjusted for gender or age) was also determined at $156 \mathrm{~mm}$ (Avdić et al., 2013), which suggests that the above value is typical of Capreolus capreolus inhabiting the Balkan region.

According to Zanneśe et al. (2006a) and Dvorak et al. (2002), the highest rate of mandibular growth is observed in the first 5 years of life. Similar observations were made in our study of roe deer from the Czech Republic. Mandibular length increases most dynamically in the first year of life, after which, this parameter increases annually by around $1 \mathrm{~cm}$ on average until the age of 4 years. Similar results were reported by Vach (1993) who observed the highest rate of mandibular growth in roe deer in the first 2 years of life.

An analysis of an increase in mandibular length in all examined individuals (aged 1 to 12 years) yielded similar results to those reported by Anděra \& Horácék (1982) in whose study, the evaluated parameter increased from $142 \mathrm{~mm}$ to $164 \mathrm{~mm}$. In our study, average mandibular length in all roe deer was determined at $151.71 \mathrm{~mm}$, and it increased from $129.27 \mathrm{~mm}$ in fawns to $147.56 \mathrm{~mm}$ in one-year-olds to $162.51 \mathrm{~mm}$ in 12-year-olds. According to Hrabe and Koubek (1991), the greatest increase in cranial length is observed between 11 and 39 months of age.

In does, mandibular growth is completed at 4 years of age. In cervids, this parameter is correlated with other, apparently unrelated physiological functions, such as fertility. Animals with better nutritional status and higher body mass reach puberty earlier, and the probability of ovulation in does exceeds 0.95 when mandibular length reaches 130 $\mathrm{mm}$. The population of one-year-old females that had calved was higher in habitats where food was more available. In does aged 1 to 7 years, age, body mass and mandibular length were significantly correlated with fertility. Fertility was most highly correlated with mandibular length (Górecki et al., 2014; Bertouille and Cromburugghe, 2002). 
A study investigating the influence of environmental factors on the mandibular length of roe deer in the Italian region of Belluno produced highly interesting results. Differences in mandibular length were determined in animals inhabiting northern and southern parts of the region. The studied locations are marked by considerable differences in altitude (167 m above sea level in the north, and $3327 \mathrm{~m}$ above sea level in the south) which influence the local climate and flora. In fawns (younger than 1 year) inhabiting the southern part of Belluno, average mandibular length was determined at $128.8 \mathrm{~mm}$ in 1990-1995 and $127.7 \mathrm{~mm}$ in 1996-2001. In the northern part of the examined region, the value of this parameter reached $123.6 \mathrm{~mm}$ and $123.9 \mathrm{~mm}$, respectively. The average mandibular length in one-year-old males was determined at $153.3 \mathrm{~mm}$ in the south and $150.00 \mathrm{~mm}$ in the north. The analyzed parameter in 2-yearold bucks reached $157.4 \mathrm{~mm}$ in the south and $154.0 \mathrm{~mm}$ in the north, and in 2-year-old does $-156.1 \mathrm{~mm}$ in the south and $153.0 \mathrm{~mm}$ in the north. The above results indicate that the southern part of the Belluno region is characterized by a more supportive environment for roe deer. The observed variations in mandibular length were crossreferenced with the density of roe deer populations in the studied areas. Animal density was higher in the north $\left(0.44\right.$ animals per $\left.\mathrm{km}^{2}\right)$, and it decreased towards the south $(0.33$ animals per $\mathrm{km}^{2}$ ). These results indicate that the density of animal populations also influences mandibular length (Zanneśe et al., 2006b).

In the present study, the average mandibular length of fawns (up to 1 year of age) from the Czech Republic was determined at $129.2 \mathrm{~mm}$, and was higher than that observed in Italian fawns. In older animals, the rate of mandibular growth was slower in Czech than in Italian roe deer. One- and 2-year-old individuals from the Czech Republic had shorter mandibles than Italian roe deer living in less favorable environmental conditions (145.7 $\mathrm{mm}$ and $151.1 \mathrm{~mm}$ on average, respectively). Our findings point to limited availability of food, high population density, a different genetic pool as well as differences in ecotype.

The results of our study and literature data can be used to develop a new strategy for monitoring the quality of local populations of European roe deer. Seasonal variations in bone size within one subpopulation are correlated mainly with environmental factors. Bone growth is most highly correlated with climate and population density. The body mass of fawns in winter, mandibular length in adult roe deer and foot length are most highly correlated with population density. In cervids, foot bones begin to grow rapidly immediately after birth, and their growth is completed relatively early, which is why this parameter is sensitive to environmental conditions. The length of hind feet varied across regions and was lower in areas characterized by lower availability of food, less supportive habitats and higher population density, regardless of gender (Zanneśe et al., 2006a).

\section{Conclusions}

The results of this study indicate that mandibular length can be a reliable and easy to measure indicator of the quality of individual roe deer and, indirectly, roe deer subpopulations. The mandibular length and body mass of roe deer can also be robust bioindicators of habitat quality. Both parameters can be used in practice by wildlife specialists and practitioners responsible for managing free-living deer populations. Further, detailed research should be extended to include other species of game and protected mammals. 


\section{REFERENCES}

[1] Anděra, M., Horáček, I. (1982): Poznáváme naše savce. - Mladá fronta, Praha.

[2] Aragon, S., Braza, F., San Jose, C., Fandos, P. (1998): Variation in skull morphology of roe deer (Capreolus capreolus) in western and central Europe. - Journal of Mammalogy 79(1): 131-140.

[3] Avdić, R., Hadžiomerović, N., Tandir, F., Bejdić, P., Ćutahija, V. (2013): Analysis of morphometric parameters of the Roe deer mandible (Capreolus capreolus) and mandible of the sheep (Ovis aries). - Veterinaria, Sarajevo 62 (1-2): 1-9.

[4] Bailey, J. A. (1984): Principles of wildlife management. - John Wiley \& Sons, Inc., New York.

[5] Bertouille, S. B., de Crombrugghe, S. A. (2002): Fertility of red deer in relation to area, age, body mass and mandible length. - Zeitschrift fur Jagdwissenschaft 48 (Suppl.): 8798.

[6] Czech Statistical Office. (2014): Statistický bulletin - Kraj Vysočina. Praha. http://www.czso.cz/csu/2013edicniplan.nsf/krajp/631302-13-xj (7. 4. 2014).

[7] Dvořák, J., Kamler, J., Šarman, J. (2002): Vyhodnocení vybraných parametrů spodních čelistí srnce obecného (Capreolus capreolus L.) z oblasti Hodonínska. - Folia Venatoria 32: 35-40.

[8] Górecki, G., Komosa, M., Skubis, J., Jakubowski, M., Skorupki, M., Napruszewska, S., Bonik H. (2014): Interrelations between mandibular parameters, age and carcass in female fallow deer (Dama dama). - Acta Zoologica Academiae Scientiarum Hungaricae 60 (3): 271-279.

[9] Hanzal, V., Ježek, M., Janiszewski, P., Kusta T. (2012):. Development of craniometric traits of wild boar (Sus scrofa). - Sylwan 156 (11): 855-862.

[10] Hewison, A. J. M., Vincent, J. P., Bideau, E., Angibault, J. M., Putman, R. J. (1996): Variation in cohort mandible size as an index of roe deer (Capreolus capreolus) densities and population trends. - Journal of Zoology 239: 573-581.

[11] Høye, T. T., Forchhammer, M. C. (2006): Early developed section of the jaw as an index of prenatal growth conditions in adult roe deer Capreolus capreolus. - Wildlife Biology 12: 71-76.

[12] Hrabě, V., Koubek, P. (1991): Postnatal skull growth in male roe deer, (Capreolus capreolus L.), between 11 months and 11 years of age. - Folia Zoologica 40 (2): 97106.

[13] Kulak, D., Wajdzik, M. (2009): Ecotype classification of the European roe deer (Capreolus capreolus L.) males on the basis of selected body parameters. - Sylwan 153 (8): 563-574.

[14] Labus, N. D., Babovic-Jaksic, T., Vasic, P. S. (2010): Sexual and age differences in craniometrics characteristics of Roe deer (Capreolus capreolus L.) from area of Mountain Prokletije. - Natura Montenegrina 9(3): 583-592.

[15] Lochman, J. (ed.). (1987): Określanie wieku zwierzyny. - PWRiL, Warszawa.

[16] Markov, G. (2014): Morphometric Variations in Skull of the Red Deer (Cervus elaphus L.) in Bulgaria. - Acta Zoologica Bulgarica 66(4): 453-460.

[17] Mayr, E. (1942): Systematics and the origin of species. - Columbia University Press, New York.

[18] Mendoza, M., Janis, C. M., Palmqvist, P. (2002): Characterizing complex craniodental patterns related to feeding behaviour in ungulates: a multivariate approach. - Journal of Zoology, London 258: 223-246.

[19] Misar, Z., Dudek, A., Havlena, V., Weiss, J. (1983) Geologie CSRS, Cesky massiv, 1. Statni Pedagogicke Nakladatelstvi, Praha.

[20] Sempéré, A. J., Sokolov, V. E., Aleksey, A., Danilkin, A. A. (1996): Mammalian Species. No. 538, Capreolus capreolus. - American Society of Mammalogists: 1-9. online: http://www.science.smith.edu/msi/pdf/i0076-3519-538-01-0001.pdf 
[21] Sheremetyeva, I. N., Sheremetyev, I. S. (2008): Skull variation in the Siberian roe deer Capreolus pygargus from the Far East: a revision of the distribution of the subspecies. European Journal of Wildlife Research 54: 557-569.

[22] StatSoft (2011): Statistica (data analysis software system) version 10. - ww.statsoft.com

[23] Stubbe, C., Passarge, H. (1979): Rehwild. - VEB Deutscher Landwirtschafts-verlag. Berlin, Germany.

[24] Vach, M. (1993): Srnčí zvěř. - Uhlířské Janovice: SILVESTRIS.

[25] Wustinger, J., Galli, J., Rozpędek, W. (2005): An osteometric study on recent roe deer (Capreolus capreolus L., 1758). - Folia Morphologica 64 (2): 97-100.

[26] Zanneśe, A., Baisse, A., Gaillard, J. M., Hewison, A. J. M., Saint-Hilaire, K., Toigo, C., van Laere, G., Morellet. N. (2006a): Hind foot length: an indicator for monitoring roe deer populations at a landscape scale. - Wildlife Society Bulletin 34 (2): 351-358.

[27] Zanneśe, A., Morellet, N., Targhetta, C., Coulon, A., Fuser, S., Hewison, A. J. M., Ramanzin, M. (2006b): Spatial structure of roe deer populations: towards defining management units at a landscape scale. - Journal of Applied Ecology 43, 1087-1097.

[28] Zedja, J., Koubek, P. (1988): On the geographical variability of roe bucks (Capreolus capreolus). - Folia Zoologica 37: 219-229. 